\title{
Plant-Based Meat Alternatives: Motivational Adoption Barriers and Solutions
}

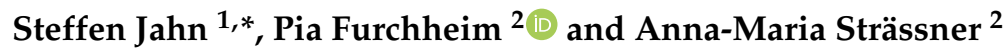 \\ 1 Department of Marketing, University of Oregon, Eugene, OR 97403, USA \\ 2 Institute of Marketing Management, ZHAW School of Management and Law, 8401 Winterthur, Switzerland; \\ Pia.Furchheim@zhaw.ch (P.F.); anna-maria.straessner@zhaw.ch (A.-M.S.) \\ * Correspondence: sjahn@uoregon.edu
}

Citation: Jahn, S.; Furchheim, P.; Strässner, A.-M. Plant-Based Meat Alternatives: Motivational Adoption Barriers and Solutions. Sustainability 2021, 13, 13271. https://doi.org/ $10.3390 /$ su132313271

Academic Editor: Michael S. Carolan

Received: 30 October 2021

Accepted: 29 November 2021

Published: 30 November 2021

Publisher's Note: MDPI stays neutral with regard to jurisdictional claims in published maps and institutional affiliations.

Copyright: (c) 2021 by the authors. Licensee MDPI, Basel, Switzerland. This article is an open access article distributed under the terms and conditions of the Creative Commons Attribution (CC BY) license (https:// creativecommons.org/licenses/by/ $4.0 /)$.

\begin{abstract}
Meat consumption is increasingly being seen as unsustainable. However, plant-based meat alternatives (PBMA) are not widely accepted yet. PBMA aim to imitate the experience of eating meat by mimicking animal meat in its sensory characteristics such as taste, texture, or aesthetic appearance. This narrative review explores the motivational barriers to adopting PBMA while focusing on food neophobia, social norms and rituals, as well as conflicting eating goals that prevent consumers from switching to a plant-based diet. Based on the key characteristics of these motivational barriers, which are informed by research findings in consumer psychology and marketing, solutions are discussed that can help counter the barriers.
\end{abstract}

Keywords: plant-based diet; plant-based meat alternatives; motivational barriers; goal conflict

\section{Introduction}

Human economic activity puts increasing pressure on the global climate and stretches the ecological, planetary boundaries [1,2]. Shifting production and consumption in today's global economy away from environmental exploitation towards more sustainable patterns ranks amongst the most crucial challenges of the 21st century [3].

In order to arrive at a sustainable future, it is important to rethink existing consumption practices. Meat consumption is in particular challenging in this regard as it places a heavy burden on the environment [4-6]. Animal-based foods have a bigger ecological footprint than plant-based foods, emitting more greenhouse gas emissions, requiring more land and nitrogen, and impacting terrestrial and aquatic biodiversity [7]. Consequently, increasing the consumption of plant-based foods, e.g., by replacing meat with meat substitutes, is normatively desirable [8] as it can be considered a 'win-win' situation with respect to both health and environmental protection [7].

Plant-based meat alternatives (PBMA) are highly processed products which try to mimic the 'meaty' characteristics of animal meat products, for example the 'bleeding' of a burger patty [9]. According to Slade [10] (p. 428), "there is a culinary race to create a plant-based burger that is indistinguishable from beef". The highly successful Beyond Burger even advertises with a "Now even meatier" claim [11]. In addition to plant-based burger patties, there are also PBMA that mimic mince, sausages, or chicken with their typical taste, texture, and physical appearance. PBMA are intended to replace the meat component in many dishes due to their similarities in form, taste, and preparation method. However, that also means that those meat substitutes are oftentimes directly compared to their 'original' counterpart meat [12].

While the market for meat substitutes is booming, a majority of consumers are often still not attracted to these products [13]. Even in Switzerland, one of the most progressive countries in the world, average meat consumption per capita (47.8 $\mathrm{kg}$ in 2019) is above the global average and willingness to eschew meat among Swiss consumers is low [14]. 
Accordingly, while more than half of the Swiss population have already tried plantbased products [15], the question arises: what keeps consumers from changing their diet for good.

With this narrative review, we aim to contribute to the conversation about PBMA adoption by presenting, summarizing, and synthesizing relevant literature that helps to understand the potential barriers of choosing meat substitutes over meat products. In particular, we aim to gain a deeper understanding of motivational adoption barriers and discuss possible solutions pertaining to how these barriers could be overcome.

\section{Materials and Methods}

Research interest in the topic of plant-based diets in general and PBMA in particular has grown rapidly over the past few years. For example, a recent comprehensive literature analysis by Fehér et al. [16] examined important characteristics of a plant-based (vegetarian) diet. Building on the theory of planned behavior, they examine perceived and objective benefits and barriers to plant-based diets. Another systematic review by Onwezen et al. [17] identified 91 articles with a focus on the drivers of the consumer acceptance of five alternative proteins: pulses, algae, insects, plant-based alternative proteins, and cultured meat.

The key motivation of the present paper is to shift the focus away from a general, broad literature overview and towards the aspect of motivational barriers that might hinder PBMA adoption. While those barriers were partly addressed in recent systematic reviews [16], the focus has rarely been on the causes of these barriers. Limited discussion on the motivational processes that keep consumers from switching to PBMA also means there is insufficient discussion on potential solutions. We aim to enrich the topical discussion of motivational barriers to PBMA adoption by incorporating insights from adjacent fields such as consumer psychology and marketing. This addition will lead to a more nuanced understanding of the motivational underpinnings of existing barriers, thereby identifying additional challenges that were not discussed in previous PBMA publications. More importantly, the symbiosis of insights from the PBMA literature with consumer psychology and marketing research sets the path to new research questions and can spark a conversation about future research avenues that might help to advance the field.

We based our narrative literature review on two thematic and distinct research streams. First, we were concerned with collecting relevant articles on the nature, benefits, and risks of PBMA, as well as (motivational) barriers to switching to a plant-based diet. In order to identify relevant articles in this domain, we combined a keyword-based search and an analysis of systematic literature reviews.

For the keyword-based search, source material published before November 2021 and available in English in one of six peer-reviewed scientific databases (Emerald, PubMed, Science Direct/Elsevier, Web of Science, Wiley) was included. We selected articles with the following keywords in the title: plant-based meat alternative(s), meat substitute(s), meat analogue(s), plant-based diet barrier(s). This step yielded a total of 612 hits in the databases. Because the majority of these articles dealt with benefits of and barriers to switching to a plant-based diet more generally, or biochemical analyses of meat substitutes, we carefully assessed each article's potential to contribute to the conversation about PBMA adoption. After title screening and removal of duplicates, we assessed 101 full texts for eligibility, of which 32 were deemed suited.

Complementing the keyword-based search, we identified seven recent reviews (six of which were published between 2019 and 2021) on the acceptance of PBMA, plant-based diets or alternative proteins more generally $[8,14,16-20]$. We searched for major themes and additional references within these reviews. Through this process, we further identified 16 articles that met our inclusion criteria.

While the first step helped us identify publications that shed light on what can motivate consumers to switch to PBMA, or make them refrain from doing so, in a second step, we intended to include articles published in adjacent fields, including consumer psychol- 
ogy and marketing. Articles from these fields have the potential to offer new insights on how the motivational barriers to PBMA adoption can be overcome. With this in mind, this paper does not seek to offer an extensive literature review on those research domains but to enrich the knowledge of PBMA barriers by integrating insights from adjacent literature streams. Through this process, we identified an additional 42 articles that mainly inform Sections 3.4 and 4 .

\section{Plant-Based Meat Alternatives: What We Know}

\subsection{Why People Decide to Ban Meat from Their Diets}

There are oftentimes multiple reasons why consumers decide to (at least gradually) remove meat from their diet [12], ranging from animal protection, protection of environmental resources, or personal health and weight control [12,16,21-23]. One of the most prominent reasons to renounce meat intake and to adopt a plant-based diet is motivated by health concerns [16,22,24-28]. Medical research indicates that high levels of (especially red and processed) meat consumption can be linked with several diseases, including cancer [29,30] and cardiovascular diseases [31-33]. Likewise, especially in high and middle-income countries, the intake of red meat is showing a negative impact on life expectancy [34]. Against this background, Izmirli and Philips [35] found that a large majority of vegetarians stated health reasons as one of the main motivators to refrain from eating meat. This finding is corroborated by self-reports indicating that vegetarians engage more with health issues [36-39] and are more weight-conscious [38-40].

While health concerns might be the reason to adopt a new diet, a recent study found that animal welfare is the main motivation to continue the diet [22]. In particular, vegetarian and/or vegan consumers link the consumption of meat to animal cruelty [35,41-43].

Besides ethical reasons (i.e., animal welfare) the role of environmental concerns in the context of meat consumption is growing. While sustainability and environmental concerns in general have been around for many years, its impact on consumer decision-making in the context of meat consumption is yet to unfold. One reason lies in the lack of awareness of the negative impact associated with meat production and consumption [25,44-46]. Only in recent years has meat consumption become a moralized issue for a growing number of consumers [47]. There is now a general consensus that meat production is associated with heightened greenhouse gas emissions and biodiversity loss [5]. In fact, livestock farming is responsible for $14.5 \%$ of greenhouse gas emissions [48] - nearly a third of agriculture's water footprint [6] - and is a major driver of deforestation [49]. From a consumption perspective, high meat-eaters cause almost twice as many carbon dioxide emissions than vegetarians [50].

\subsection{Plant-Based Meat Alternatives (PBMA)}

The alternative protein market is growing rapidly [51]. Besides alternative animalbased protein sources such as edible insects or lab-grown meat (i.e., meat produced in the lab without raising and slaughtering the animal, also termed clean meat, cultured meat, in vitro meat, or artificial meat), non-meat protein sources are a promising alternative to traditional meat. The market for non-meat proteins is booming and there is a variety of different products available in the market (see Figure 1). Non-meat protein sources vary in the extent to which they are processed. Foods are considered 'natural' if they are free from human intervention, such as removing negatives or adding positives [52,53], and examples of natural non-meat proteins are algae, lentils, pulses, soybeans, or fungi. These proteins are also typical ingredients in vegetarian and vegan cuisine. 


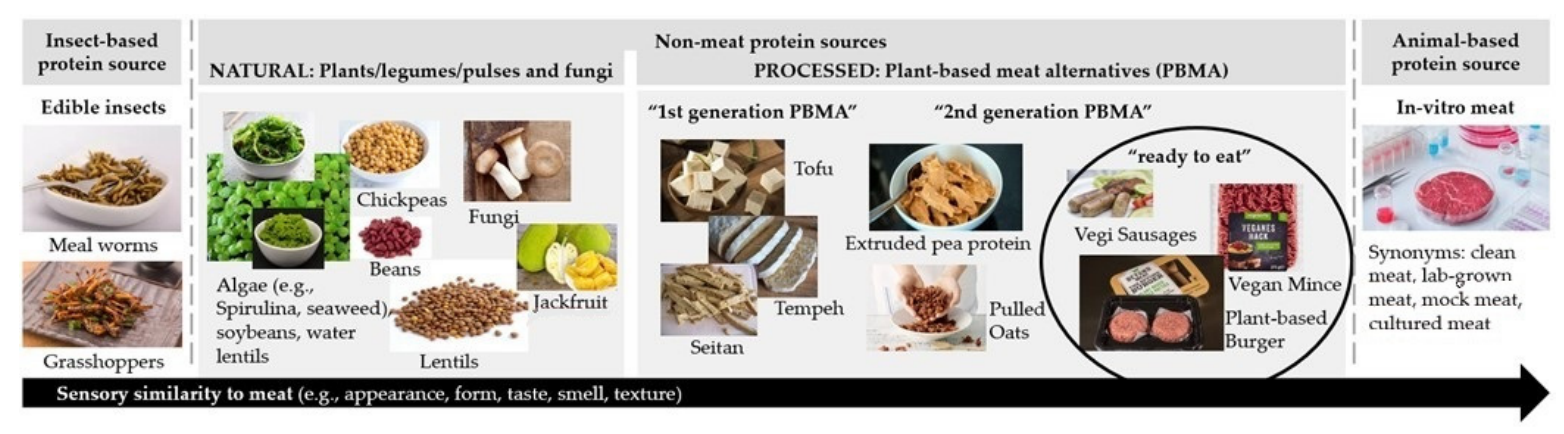

Figure 1. Overview of alternative protein sources.

Foods are considered 'processed' if they have gone through different production steps or if other ingredients have been added to create the final product. Due to their comparable texture to processed meat products, these products are often perceived and consumed as plant-based meat alternatives (PBMA, also referred to as meat substitutes or meat analogues). Some of them, for example, tofu and tempeh, have been consumed in Asia for centuries [54]. This 'first generation' of PBMA were mainly based on soy. While Asian consumers perceive soy as a traditional food in their diet, Western consumers often have a negative image of soy [55]. Moreover, consumers in many countries hold unjustified concerns about genetically modified foods, and soy is often among those foods of concern [56]. 'Second generation' PBMA use different ingredients, are more highly processed, and thus manage to improve the sensory experience. New technologies such as extrusion has facilitated the development of food products from extracted pea or oat protein, which create a meat-like structure $[19,20]$. As part of this second generation PBMA, 'ready to eat' PBMA have recently been entering a market that tries to imitate the meaty original and tends to be rather highly processed.

PBMA have the best chance of successfully replacing meat when they closely resemble highly processed meat products in taste and texture and are offered at competitive prices [18]. The PBMA market in Europe is predicted to increase from 1.5 billion EUR in 2018 to 2.4 billion EUR in 2025 [57]. In the remainder, we focus on the second generation of PBMA, which is growing in popularity but still holds some ambiguity, and thus shows low levels of consumer acceptance.

\subsection{Barriers to PBMA Consumption}

\subsubsection{Structural Adoption Barriers}

Several authors have examined barriers that hinder consumers from limiting or banning meat and switching to a plant-based diet (for recent reviews, see [8,14,16-20]). Some of these barriers are predominantly structural and are tied to the general demand of PBMA. For example, it may not always be convenient to purchase PBMA as they have limited availability in grocery stores or restaurants [22]. Another structural barrier is the relative newness of PBMA and a corresponding lack of exposure [12]. We know from experimental research that, when foods are exposed as a 'normal choice option', such as becoming the default option in a menu, adoption improves [58]. Obviously, over time, an innovative product will become more normal. In the short run, however, the innovative nature of PBMA, paired with limited demand, results in them being relatively costly. Indeed, consumers perceive plant-based (vegetarian) diets to be much more costly than traditional meat diets [59-63]. Notably, in the next few years, Beyond Meat plant-based hamburger patties will likely remain more expensive than the equivalent amount of ground beef [64].

In summary, over time and with increasing consumer demand, the structural barriers will likely diminish and may even disappear entirely. According to self-reports, consumers would eat more plant-based foods if these structural barriers disappeared [22]. Among a sample of 186 Copenhageners, for example, $13.4 \%$ indicated they would eat more plantbased if it was cheaper or if it was more convenient to get $(10.3 \%)$, took less time to prepare $(9.3 \%)$, and if there was a greater selection at supermarkets $(7.2 \%)$ or if more restaurants 
offered plant-based meals (7.2\%) [22]. Although one must be critical with self-reported data and the limited predictive power of attitudes for actual behavior [65], this can be considered a promising sign for PBMA and associated sustainability benefits.

\subsubsection{Motivational Adoption Barriers}

Besides structural barriers, motivational barriers exist that will likely persist regardless of improvements in availability, exposure, and affordability. We summarize these motivational barriers as follows: (1) food neophobia, (2) social norms and rituals, and (3) conflicting eating goals. Table 1 lists these barriers as well as exemplary research findings. The motivational barriers jointly contribute to prevailing meat attachment, a positive emotional bond people have with meat [66]. Overcoming meat attachment is a key challenge for increasing PBMA adoption.

First, given that PBMA are considerably new to many consumers, food neophobia, which describes a general reluctance to ingest novel foods and highly correlates with disgust [67], can act as a barrier to those consumers that consider the product or category to be too unfamiliar $[12,68]$. An interesting analogy to one's willingness to try PBMA would be international students' willingness to try novel foods in a country of study. Research has shown that international students tend to be food neophobic, which adversely influenced their diets [69]. In the case of PBMA, one might argue that meat substitutes become more common over time, rendering food neophobia more of a structural barrier that will slowly disappear with the increasing success of PBMA. However, an important aspect of food neophobia is a consumer's lack of personal experience, and personal experience with a meat substitute can increase liking [70]. This implies that, even if PBMA become more common and thus generally familiar, the motivational barrier of food neophobia could persist as long as consumers are unwilling to personally experience the novel food. On a positive note, there are large individual differences in the extent of food neophobia [67], meaning that this motivational barrier to adopt PBMA exists only among a fraction of all consumers.

Table 1. Motivational Barriers to PBMA Adoption.

\begin{tabular}{cll}
\hline Motivational Barrier & \multicolumn{1}{c}{ Research Findings } \\
\hline Food neophobia & - & A general reluctance to eat new foods hinders PBMA adoption [12] \\
\hline $\begin{array}{c}\text { Social norms } \\
\text { and rituals }\end{array}$ & - $\begin{array}{l}\text { There is a strong link between meat consumption and the celebration } \\
\text { of important holidays (e.g., Thanksgiving or Christmas) [62,71] } \\
\text { Consumers find it difficult to avoid meat when most of their family } \\
\text { and friends consume meat [62,71,72] }\end{array}$ \\
& People lack knowledge of how to eat in an alternative way [28,60,68] \\
Masculine-stereotyped dietary practice stands in the way of reduced \\
meat consumption [73,74]
\end{tabular}


Second, the process of cooking and eating is oftentimes deeply connected to social norms and rituals. In this regard, the underlying legacy of 'meat traditions' presents a strong barrier. For centuries, human society and meat have co-evolved, resulting in deeply rooted traditions and rituals around hunting, slaughtering, cooking, and eating meat [82]. There are still strong cultural links between the consumption of meat and the celebration of special events such as holidays $[62,71]$. The cultural influence may be particularly visible in terms of many men's perception that eating meat is masculine, which results in a reduced willingness to consider vegetarianism, among others [73]. While traditional masculine stereotypes are culturally ingrained, they are not set in stone. A recent article by de Backer and colleagues [74] showed that men who identify with nontraditional forms of masculinity had a lower attachment to meat and a stronger tendency to reduce their meat consumption.

Besides cultural influence, the immediate social environment strongly influences food and eating habits. Families likely exert more influence at younger ages, shaping dietary patterns, individual and culturally related taste preferences, as well as specific eating rules [83]. Beyond this influence of childhood norms, current family members, such as partners or children, can be a barrier for the adoption of PBMA. People may find it difficult to avoid meat when family and friends (religiously) are unwilling to eat a plant-based $\operatorname{diet}[28,72]$.

Moreover, food preparation rituals can play an important role. While veteran cooks have rituals of preparing meat dishes such as Sunday roast, BBQ, Thanksgiving turkey or lamb tajine, they may lack the knowledge to prepare PBMA [28,61,71,84]. While flexitarians are split on the question whether meat or meat substitutes are easier to prepare, selfdescribed omnivores find meat to be easier to prepare than meat alternatives [85]. In a related manner, many people may also lack knowledge of how to eat in an alternative way $[60,68]$. Consequently, entering a new, plant-based lifestyle seems to pose a challenge to the pro-meat narratives on passion, tradition, and local production and consumption [75].

Third, the superior sustainability and health of PBMA may not be enough to convince consumers to switch, as long as they hold the conflicting eating goals which they also deem relevant. Typically, consumers pursue not just one but multiple goals at the same time [86]. This is true for food consumption as well: we desire food that is tasty but also food that is healthful (or at least not unhealthful) $[87,88]$. Moreover, we increasingly want our foods to be more environmentally sustainable [89]. Relevant for our understanding of motivational adoption barriers for PBMA is that the simultaneous presence of multiple goals may create a conflict between these goals that needs to be resolved [86]. Before we address potential resolutions to goal conflicts, we specify the conflicting eating goals that may stand in the way of purchasing PBMA.

\subsection{Alternative Eating Goals and How They Can Stand in the Way of PBMA Adoption \\ 3.4.1. Indulgence}

Perhaps the biggest challenge for the adoption of PBMA is the common belief that meat is among the most enjoyable elements of a diet $[28,60,72,77]$. Indeed, in many cultures, meat is the central part of a dish [61,90], and meat is regularly listed among people's preferred foods [91,92]. In a recent study, Michel et al. [85] found that the most frequently elicited association of meat was "delicious", while "disgust" was the third-most frequent association to meat alternatives. Specific reasons for perceiving meat as more enjoyable might be that consumers value its smell, taste, and juiciness [93].

Besides the indulgence benefits of meat, it is fair to say that, when it comes to taste, there is some variety among PBMA. In particular, the 'first generation' products that rely on soy have a different texture that not all consumers may like [55]. While 'second generation' products are much improved, consumers who have tried 'tasteless' PBMA may not feel compelled to try again. This is particularly true for the majority of consumers who may not be aware of recent quality improvements.

Further contributing to the perceived hedonic superiority of meat over PBMA is the general intuition that healthier foods are less tasty [94]. This bias is rooted in a tendency to 
classify food products either as nutritious and good for you (called 'virtues') or indulgent yet harmful ('vices') [95]. Vice products provide an immediate pleasurable experience, "such as the good taste of chocolate cake" [96] (p. 168) but often contribute to long-term health problems [31-33]. Virtue products tend to be construed in relation to vices [96] and are thus perceived as 'the reasonable choice' which in the short run, however, is less gratifying and appealing. Although most discussions of virtue foods center around them being more nutritious and healthful [96], the increased sustainability of PBMA clearly is another reason to view them as virtues, especially in relation to meat and its negative impact on the environment.

To summarize, the consumption of meat constitutes a means for the goal of indulgence (or food enjoyment), but a hindrance for the goal of sustainability or health. By contrast, consumption of PBMA constitutes a means towards the goal of healthiness or sustainability, that is accompanied by the (biased) perception of being less indulgent. Against this background, it does not come as a surprise that consumers actually perceive PBMA as having lower sensory attractiveness $[12,61,68]$. Consequently, when people encounter PBMA, their initial response may be both positive (e.g., it looks like real meat, is better for the environment, and no animal had to be killed), making them want to approach the PBMA and eat it, as well as negative (e.g., it probably does not have great taste), making them want to avoid the product. Notably, a major reason for flexitarians that keeps them from switching entirely to a plant-based diet is their love for the taste of meat [21,68].

The discussion has shown that, if meat products are classified as vices with indulgent qualities and PBMA as virtues characterized by being sustainable, these two eating goals are in conflict and need to be resolved when making a purchase decision. Research indicates that virtues represent a more prudent choice for consumers and are thus chosen in situations that require justification of one's choices or where consumers are able to control their desire for indulgence $[95,97,98]$. However, there is an entire literature stream devoted to the examination of conditions under which self-control fails and vices are consumed more frequently. This literature mostly draws from concepts of ego depletion $[99,100]$ and psychological licensing [88]. In a nutshell, people tend to exert less self-control when they are depleted [100], resulting in increased consumption of indulgent vices [101], and consumers' choice and consumption of healthful versus indulgent food depends to some extent on their previous behaviors [102]. For example, the majority of participants in a study by Dhar and Simonson [102] said that eating a pizza dish was more enjoyable after a workout rather than watching television. Chang and Chu [103] demonstrated that making a purchase with a cause (versus a purchase with a discount) increased subsequent choice of indulgent food. Behaving in a positive way thus provides people with a license to indulge afterwards.

Taken together, if consumers perceive meat to taste better and be more enjoyable to eat, this may overrule their desire to purchase more sustainable alternatives such as PBMA. This categorization can be particularly critical, as it is likely that many consumers are mentally depleted when doing their grocery shopping. First, the number of choices and decisions can be perceived to be overwhelming [104] and, second, physiological aspects such as hunger or low levels of glucose can influence the level of ego depletion, self-control, and decision-making $[105,106]$.

\subsubsection{Supply of Essential Nutrients}

We have mentioned that PBMA tend to be healthier than meat, and that the main reasons to reduce or ban the consumption of meat among flexitarians include health concerns $[24,25,27]$. Banning meat from one's diet has another health-related consequence, however. Theoretically, a purely plant-based diet could lead to missing out on essential nutrients, such as calcium, iron, and vitamin B12 [107,108]. Even though a balanced vegan diet can get all the nutrients people need $[28,81,108,109]$, consumers are often unsure about the benefits of alternative proteins and underestimate the benefits of plant-based 
diets [60]. For example, Corrin and Papadopoulos [77] showed that a common belief among consumers is that animal meat contains important nutrients that cannot be substituted.

The belief that PBMA may not guarantee the supply of all essential nutrients again conflicts with the goal of banning meat for health and sustainability reasons. If PBMA are presumed to fall short on nutrients such as iron and vitamin B12, the perceived health benefit of PBMA decreases. This view is supported by a survey among 404 Australian consumers: while $67 \%$ either agreed or strongly agreed with the statement that PBMA are more environmentally friendly than traditional meat, only $32 \%$ (strongly) agreed that PBMA were more nutritious [110].

However, studies have shown that the comparison of the nutritional composition between ultra-processed PBMA and traditional meat products leads to inconclusiveness on which is generally healthier [111]. In fact, it seems to depend on the individual product and which ingredients are used [111]. PBMA may have some role in improving human and planetary health; however, according to Hu et al. [9], there is no evidence yet to suggest that they can substitute for healthy diets focused on minimally processed plant-based alternatives.

In addition, Tso and Forde [81] have highlighted that novel ultra-processed meat alternatives oftentimes exceed the reference diet in terms of undesirable nutrients such as saturated fat, sodium, and sugar. This presents a challenge in two directions as it does not only challenge the health perception in comparison to meat but also may lead to inferior quality and health perceptions compared to minimally processed plant-based alternatives. A decreased health benefit of PBMA could jeopardize perceptions of PBMA as true virtues, thereby increasing the challenge of being selected over traditional meat, which are allegedly more indulgent. Consequently, less people will be willing to consume PBMA on a regular basis.

\subsubsection{Naturalness}

In addition to perceptions of inferior indulgence and health benefits, a third concern focuses on the perceived un-naturalness of ultra-processed, plant-based products [78-80]. We mentioned that foods are considered 'natural' if they are free from human intervention, such as removing negatives or adding positives. According to the International Food Information Council Foundation, there are four types of processed foods, depending on the level of processing. From the least processed to the most processed, these are: 'minimally processed', 'processed for preservation', 'mixture of combined ingredients', and 'ready to eat' [112]. Second-generation PBMA tend to fall at the high end of the processing level continuum (ready-to-eat foods).

The degree of naturalness matters as consumers have been shown to consider processing levels when assessing the overall nutrition of a product [113]. In general, non-processed products would be evaluated as being healthier than highly processed foods [114-116]. Moreover, Prada et al. [117] found that, while many consumers believe organic whole food to be healthier than their conventional counterparts, they are unsure whether the same health advantage exists in the case of processed organic foods. Against this background, non-organic, synthetically produced food products such as PBMA may be perceived as less healthful. Again, this would reduce their attractiveness [116]. Consumers would then weigh sustainability against indulgence and even healthfulness, making it difficult for PBMA adoption. Ironically, 'fixing' the problem of essential nutrient supply by fortifying PBMA with calcium, iron, and B12 can further strengthen the image of unnaturalness [118] and further increase the challenge.

\section{Solutions to Increase Consumption of Plant-Based Meat Alternatives \\ 4.1. Solutions to Counter Food Neophobia}

It may be difficult to promote plant-based diets among consumers with high food neophobia, as neophobia is very difficult to transform [12]. Yet, one way to reduce neophobia is to make novel foods resemble familiar foods [119], which is the central idea behind PBMA. Against this background, the "Now even meatier" claim on the Beyond Burger can 
be seen as a good tactic to spark interest in PBMA. Product improvement is therefore seen as the most promising path to counter food neophobia, while providing information on environmental benefits is not likely to be effective in this regard [12].

Beyond product improvement, marketers could try to spark curiosity or turn supposed disadvantages into strength. Labels can be used to highlight aspects of PBMA that grab consumers' attention and make them reconsider their typical choices. For example, recent consumer research has shown that unattractive produce can be sold more effectively, if it contained "ugly" labels [120]. Notably, this is a different labeling strategy than the more common claims that focus on scientifically verifiable characteristics (e.g., "low fat" or "high vitamins") or the food's natural preservation (e.g., "no additives" or "unprocessed") [52]. This difference is important as sustainability labeling faces the problem that even certified claims are not always trusted [121]. Such skepticism is partly due to consumers using different sources and types of knowledge to decode sustainability claims, in addition to the sheer number of different claims [121]. A label that aligns with the visual assessment of the food (such as "ugly" labels) has a clear advantage in this regard. Using creative labels could therefore be a way to increase consumers' willingness to try PBMA.

\subsection{Solutions to Counter Social Norms and Rituals}

Social norms are difficult to ignore, which effectively leaves two solutions to counter their inhibiting influence on a 'meat-free' diet. The first option would be to change these norms, but this is admittedly a process that takes time. We have noticed, however, that younger generations are much more willing to eat plant-based and try novel foods [122,123]. In a study among Australian consumers conducted in 2004, $42 \%$ of respondents aged 60 or older said they do not want to change their eating habits or routines, while $21 \%$ of respondents aged 20-44 felt that way [72]. In a recent study, younger age was associated with increased willingness to try in vitro meat [124], which points to a slow shift in norms over time. In these situations, it is advisable to communicate what is called a trending norm and not the prevalent norm [125]. Instead of highlighting the current state of a behavior (i.e., $\mathrm{X} \%$ of a reference group show the 'static norm'), trending norms emphasize the increasingly changing norm over time to elicit (pre-) conformity to this change. Compared to static norms, the dynamic norm information that increasingly more people are beginning to engage in sustainable behavior can effectively foster sustainable behavior that is not yet the norm [126].

The second option is to create new norms and rituals that do not have to replace existing norms right away. For example, the Plant-Based Foods Association (PBFA) has said that one-third of Americans are "actively reducing" their intake of meat and dairy by participating in "Meatless Mondays", opting for an occasional veggie burger or stocking their fridges with plant milks alongside dairy. While these numbers may be inflated, an opportunity waits for rituals that involve PBMA regardless. Likewise, activities such as the Vegan Challenge on Instagram or vegan TikTok influencers have the potential to offer a fun way to trying out new food and establish meat-free routines. To some extent, these activities may even incentivize consumers with moderate-high levels of food neophobia to at least give PBMA a try. Context is important in this to highlight the positive aspects of eating PBMA, rather than focusing on the negative aspect of eating meat and how it can be overcome. In line with research that suggests that medical recommendations such as "cut out red meat" may threaten a man's masculinity and thereby, opposite to their intention, cause these men to eat more meat [73], negative messaging could backfire.

\subsection{Solutions to Minimize the Influence of Conflicting Eating Goals}

Supposedly, the biggest challenge to PBMA adoption is minimizing the inhibiting influence of conflicting eating goals. While continuation in the path towards increased mimicking of traditional meat could be useful in some areas, it may have detrimental effects in others. For example, we have mentioned that PBMA product that closely resemble traditional meat can help overcome food neophobia, and it may also boost perceptions 
that PBMA can actually be as indulgent as meat. This strategy, however, can backfire with regard to the goal of consuming food that is natural. The more closely PBMA resemble meat dishes, the more obvious the highly processed state will become.

Ironically, increasing (perception of) the indulging qualities of PBMA may blur the boundaries between PBMA being virtue or vice products. For example, associations of the product looking like meat, feeling like meat, and tasting like meat may lead some consumers to infer the PBMA might be healthier than meat but substantially less healthful than other plant-based dishes. This way, PBMA could be perceived as a relative virtue when compared with meat but a relative vice when compared with tofu. For marketers, this is problematic because consumer responses to products, assortments, and promotions have been shown to differ between virtue and vice categories [95,97,98,127,128]. For example, visual cues on the package might require more cognitive elaboration for virtue than for vice food [129]. Besides elaborating package information, even the nature of virtue and vice foods requires different levels of cognitive effort from consumers [130] in exerting self-regulation to promote utilitarian consumption [131] or indulging self-licensing to promote hedonic consumption [132]. Because of its higher hedonic appeal [133], vice food is more likely to be consumed on impulse [134], requires a greater need for self-control by consumers [95], and drives a higher willingness to pay [96]. Virtue food, on the other hand, is more likely to be preferred to vice food for public than for private consumption [135]. Context-specific construal of PBMA as either relative virtue or vice thus makes it difficult for marketers to decide on the way product information is communicated.

If marketers aim to counter the indulgence associations with more 'virtuous associations,' another product-related solution is food fortification. Food fortification means that PBMA could be enriched with iron and vitamin B12 as another way to resemble meat and make sure that banning meat from one's diet will not lead to any health deficits. It has to be noted that the increasing purchase intention of fortified foods is challenging as it requires favorable attitudes towards food fortification, a perceived personal benefit from its consumption, cultural appropriateness, and high awareness that, without this fortification, there could be negative consequences for society [136].

Despite these challenges, food fortification can be seen as an essential component to reach sustainability goals while maintaining supply of all necessary nutrients [137]. It is this integration of health and (environmental) sustainability goals that could prove particularly effective in promoting PBMA. For example, results of a choice-based conjoint experiment have revealed that, in order to boost preference and willingness to pay, meat substitutes should be organic and local [138]. As healthiness and environmental friendliness of foods appear to be connected in many consumers' minds, Lazzarini et al. [139] suggest combining these two issues in communications, interventions, and education to promote dietary shifts towards a more sustainable diet. This means that all communication of PBMA should emphasize both health and environmental benefits. Interestingly, this suggestion fits with the previously mentioned requirements for increasing the purchase intention of fortified foods: while the health benefits are personal consumption benefits, the environmental consequences refer to societal outcomes. One may conclude that health communication could more broadly utilize the framework suggested in Jahn et al. [136].

In summary, two strategies emerge with the potential to minimize the inhibiting influence of alternative eating goals. The first strategy targets indulgence and seeks to minimize the perceived difference in indulgence of meat versus PBMA. Technological advancements suggest this could become a likely scenario. Yet, the benefit of increased perceptions of indulgence could simultaneously activate unfavorable health associations, which could weaken the net impact of this approach. The second strategy targets the health goal and can be seen as most effective if healthiness and sustainability communications are combined and each aspect is explicitly addressed. 


\section{Discussion and Future Research Opportunities}

The environmental impact of dieting has become an increasingly important concern. While substituting meat with plant-based proteins is widely considered an essential component to the sustainability of food systems, many barriers exist that stand in the way of plant-based protein adoption. In this review, we discussed barriers to the adoption of plantbased meat alternatives (PBMA). Special emphasis was placed on the motivational barriers, (1) food neophobia, (2) social norms and rituals, and (3) conflicting eating goals (indulgence, healthiness, naturalness). The examination of eating goal conflict has a long history in behavioral research [140-142], yet explicit consideration in literatures on meat substitutes is missing. We have outlined different strategies-communication of similarities to meat versus communication of superior health and environmental friendliness-, but more research is necessary to answer questions about which strategy could be more effective overall.

For example, the close similarity of PBMA to meat in terms of taste, smell, visual appearance, and texture can be seen as a major asset to overcome food neophobia and even social norms and rituals. However, one may wonder if this approach resonates well with vegans and vegetarians who have banned meat for ethical reasons. PBMA could be seen as a constant reminder of everything this consumer group rejects and thus cause resistance. However, even on a more subconscious level, claims such as "Now even meatier" make meat associations salient, which may trigger disgust. More research is necessary to address this question.

Another fruitful area for future research is the improved understanding of flexitarians' response to PBMA. Flexitarians seem like the perfect target group for PBMA: they still have meat cravings yet are open to plant-based diets. Hence, PBMA can be seen as offering "best of both worlds" for them, similar to products described as healthful indulgences such as chocolate containing antioxidants [87]. At first glance, PBMA could therefore alleviate the stress flexitarians experience when they have to choose between meat and plant-based proteins [143]. However, sustainability is a complex concept and several means exist for attaining this goal, including buying locally or reducing meat consumption [80]. In this regard, an environmentally conscious consumer could face a trade-off between purchasing organic meat from a local farm or choosing PBMA, whose provenance is unknown and ingredients are mass produced. Both choices would offer some progress towards the sustainability goal; however, which choice would be perceived to be more sustainable and thus more favorable? Does PBMA present the "best of both worlds" or would a more conscious selection of the farmer (locally and organic meat) be a more attractive choice? More research is needed that investigates the different trade-offs consumers are facing and subsequent coping strategies to overcome those conflicts.

Regarding the fortification of PBMA with iron or vitamin B12, we do not know if consumers think it is appropriate. Research indicates that the perceived appropriateness of fortification is product-specific and not a function of how processed the food is [136]. That is, even for highly processed food such as PBMA, fortification might be seen as inappropriate. A recent study showed that participants were split on the question of whether PBMA should contain iron to match traditional meat [110]. We need more data, especially about different segments, to gain a better understanding of this important topic.

A related question is whether meat-mimicking texture and flavor could actually decrease concerns over insufficient nutrient content. In other words, will consumers perceive "hyper realistic" PBMA to contain sufficient iron and vitamin B12? While this notion may seem implausible at first, research has shown that informing consumers about a brand donating to the American Heart Association can increase unrelated inferences about product healthfulness [144] and product quality [145]. If this benevolent halo effect would actually occur for PBMA, this means that the goal conflict between sustainability and the sufficient supply of key nutrients can be reduced without creating another conflict about naturalness. 
To conclude, we hope that the proposed solutions to counter motivational barriers of PBMA adoption allow food marketers to act and increase the overall attractiveness of these alternative proteins, thereby contributing more to the sustainability of food systems.

Author Contributions: Conceptualization, S.J. and P.F.; methodology, S.J., P.F. and A.-M.S.; writing —original draft preparation, S.J., P.F. and A.-M.S.; writing—review and editing, S.J., P.F. and A.-M.S.; visualization, S.J. and A.-M.S.; supervision, S.J. and P.F. All authors have read and agreed to the published version of the manuscript.

Funding: This research received no external funding.

Institutional Review Board Statement: Not applicable.

Informed Consent Statement: Not applicable.

Acknowledgments: We thank the three anonymous reviewers for their valuable guidance.

Conflicts of Interest: The authors declare no conflict of interest.

\section{References}

1. IPCC. Summary for Policymakers. In Climate Change 2013: The Physical Science Basis: Contribution of Working Group I to the Fifth Assessment Report of the Intergovernmental Panel on Climate Change; IPCC: Cambridge, UK; New York, NY, USA, 2013. Available online: https:/ / www.ipcc.ch/site/assets/uploads/2018/02/WG1AR5_all_final.pdf (accessed on 10 November 2021).

2. Whiteman, G.; Walker, B.; Perego, P. Planetary Boundaries: Ecological Foundations for Corporate Sustainability. J. Manag. Stud. 2013, 50, 307-336. [CrossRef]

3. Forrest, R.; Kearns, A. Social Cohesion, Social Capital and the Neighbourhood. Urban Stud. 2001, 38, 2125-2143. [CrossRef]

4. Hoek, A.C.; Malekpour, S.; Raven, R.; Court, E.; Byrne, E. Towards environmentally sustainable food systems: Decision-making factors in sustainable food production and consumption. Sustain. Prod. Consum. 2021, 26, 610-626. [CrossRef]

5. Godfray, H.C.J.; Aveyard, P.; Garnett, T.; Hall, J.W.; Key, T.J.; Lorimer, J.; Pierrehumbert, R.T.; Scarborough, P.; Springmann, M.; Jebb, S.A. Meat consumption, health, and the environment. Science 2018, 361, eaam5324. [CrossRef]

6. Gerbens-Leenes, P.W.; Mekonnen, M.M.; Hoekstra, A.Y. The water footprint of poultry, pork and beef: A comparative study in different countries and production systems. Water Resour. Ind. 2013, 1-2, 25-36. [CrossRef]

7. Willett, W.; Rockström, J.; Loken, B.; Springmann, M.; Lang, T.; Vermeulen, S.; Garnett, T.; Tilman, D.; DeClerck, F.; Wood, A.; et al. Food in the Anthropocene: The EAT-Lancet Commission on healthy diets from sustainable food systems. Lancet 2019, 393, 447-492. [CrossRef]

8. Weinrich, R. Opportunities for the Adoption of Health-Based Sustainable Dietary Patterns: A Review on Consumer Research of Meat Substitutes. Sustainability 2019, 11, 4028. [CrossRef]

9. Hu, F.B.; Otis, B.O.; McCarthy, G. Can Plant-Based Meat Alternatives Be Part of a Healthy and Sustainable Diet? JAMA 2019, 322, 1547-1548. [CrossRef]

10. Slade, P. If you build it, will they eat it? Consumer preferences for plant-based and cultured meat burgers. Appetite 2018, 125, 428-437. [CrossRef]

11. Beyond Meat. Meat the New Meatier Beyond Burger with Marbling That Melts and Tenderizes Like Beef! Available online: https:/ / www.beyondmeat.com/whats-new / meat-the-new-meatier-beyond-burger-with-marbling-that-melts-andtenderizes-like-beef (accessed on 28 October 2021).

12. Hoek, A.C.; Luning, P.A.; Weijzen, P.; Engels, W.; Kok, F.J.; de Graaf, C. Replacement of meat by meat substitutes. A survey on person- and product-related factors in consumer acceptance. Appetite 2011, 56, 662-673. [CrossRef] [PubMed]

13. Gebhardt, B. Plant-Based for the Future. In Insights on European Consumer and Expert Opinions; University of Hohenheim: Hohenheim, Germany, 2021.

14. Hartmann, C.; Siegrist, M. Consumer perception and behaviour regarding sustainable protein consumption: A systematic review. Trends Food Sci. Technol. 2017, 61, 11-25. [CrossRef]

15. Coop. Plant Based Food Report: Studie Zum Pflanzenbasierten Genuss in der Schweiz. 2021. Available online: https:/ / www.coop.ch/content/dam/Medien/Medienmitteilung/2020/Pflanzenbasierte-Ersatzprodukte-werden-immerbeliebter/Coop-Plant-Based-Food-Report-2021-DE.pdf (accessed on 29 October 2021).

16. Fehér, A.; Gazdecki, M.; Véha, M.; Szakály, M.; Szakály, Z. A Comprehensive Review of the Benefits of and the Barriers to the Switch to a Plant-Based Diet. Sustainability 2020, 12, 4136. [CrossRef]

17. Onwezen, M.C.; Bouwman, E.P.; Reinders, M.J.; Dagevos, H. A systematic review on consumer acceptance of alternative proteins: Pulses, algae, insects, plant-based meat alternatives, and cultured meat. Appetite 2021, 159, 105058. [CrossRef]

18. Michel, F.; Knaapila, A.; Hartmann, C.; Siegrist, M. A multi-national comparison of meat eaters' attitudes and expectations for burgers containing beef, pea or algae protein. Food Qual. Prefer. 2021, 91, 104195. [CrossRef]

19. Ismail, I.; Hwang, Y.-H.; Joo, S.-T. Meat analog as future food: A review. J. Anim. Sci. Technol. 2020, 62, 111-120. [CrossRef] 
20. He, J.; Evans, N.M.; Liu, H.; Shao, S. A review of research on plant-based meat alternatives: Driving forces, history, manufacturing, and consumer attitudes. Compr. Rev. Food Sci. Food Saf. 2020, 19, 2639-2656. [CrossRef]

21. de Backer, C.J.S.; Hudders, L. Meat morals: Relationship between meat consumption consumer attitudes towards human and animal welfare and moral behavior. Meat Sci. 2015, 99, 68-74. [CrossRef]

22. Fresán, U.; Errendal, S.; Craig, W.J. Influence of the Socio-Cultural Environment and External Factors in Following Plant-Based Diets. Sustainability 2020, 12, 9093. [CrossRef]

23. Bryant, C.J. We Can't Keep Meating Like This: Attitudes towards Vegetarian and Vegan Diets in the United Kingdom. Sustainability 2019, 11, 6844. [CrossRef]

24. Apostolidis, C.; McLeay, F. To meat or not to meat? Comparing empowered meat consumers' and anti-consumers' preferences for sustainability labels. Food Qual. Prefer. 2019, 77, 109-122. [CrossRef]

25. Lentz, G.; Connelly, S.; Mirosa, M.; Jowett, T. Gauging attitudes and behaviours: Meat consumption and potential reduction. Appetite 2018, 127, 230-241. [CrossRef]

26. Sun, C.; Ge, J.; He, J.; Gan, R.; Fang, Y. Processing, Quality, Safety, and Acceptance of Meat Analogue Products. Engineering 2021, 7, 674-678. [CrossRef]

27. Mylan, J. Sustainable Consumption in Everyday Life: A Qualitative Study of UK Consumer Experiences of Meat Reduction. Sustainability 2018, 10, 2307. [CrossRef]

28. Kemper, J.A.; White, S.K. Young adults' experiences with flexitarianism: The 4Cs. Appetite 2021, 160, 105073. [CrossRef]

29. Bouvard, V.; Loomis, D.; Guyton, K.Z.; Grosse, Y.; Ghissassi, F.E.; Benbrahim-Tallaa, L.; Guha, N.; Mattock, H.; Straif, K. Carcinogenicity of consumption of red and processed meat. Lancet Oncol. 2015, 16, 1599-1600. [CrossRef]

30. Domingo, J.L.; Nadal, M. Carcinogenicity of consumption of red meat and processed meat: A review of scientific news since the IARC decision. Food Chem. Toxicol. 2017, 105, 256-261. [CrossRef] [PubMed]

31. Crowe, F.L.; Appleby, P.N.; Travis, R.C.; Key, T.J. Risk of hospitalization or death from ischemic heart disease among British vegetarians and nonvegetarians: Results from the EPIC-Oxford cohort study. Am. J. Clin. Nutr. 2013, 97, 597-603. [CrossRef]

32. Oomen, C.M.; Ocké, M.C.; Feskens, E.J.M.; van Erp-Baart, M.-A.J.; Kok, F.J.; Kromhout, D. Association between trans fatty acid intake and 10-year risk of coronary heart disease in the Zutphen Elderly Study: A prospective population-based study. Lancet 2001, 357, 746-751. [CrossRef]

33. Harguess, J.M.; Crespo, N.C.; Hong, M.Y. Strategies to reduce meat consumption: A systematic literature review of experimental studies. Appetite 2020, 144, 104478. [CrossRef] [PubMed]

34. Ranabhat, C.L.; Park, M.-B.; Kim, C.-B. Influence of Alcohol and Red Meat Consumption on Life Expectancy: Results of 164 Countries from 1992 to 2013. Nutrients 2020, 12, 459. [CrossRef] [PubMed]

35. Izmirli, S.; Phillips, C.J. The relationship between student consumption of animal products and attitudes to animals in Europe and Asia. Br. Food J. 2011, 113, 436-450. [CrossRef]

36. Hoek, A.C.; Luning, P.A.; Stafleu, A.; de Graaf, C. Food-related lifestyle and health attitudes of Dutch vegetarians, non-vegetarian consumers of meat substitutes, and meat consumers. Appetite 2004, 42, 265-272. [CrossRef] [PubMed]

37. Siegrist, M.; Hartmann, C. Impact of sustainability perception on consumption of organic meat and meat substitutes. Appetite 2019, 132, 196-202. [CrossRef]

38. Hartmann, C.; Ruby, M.B.; Schmidt, P.; Siegrist, M. Brave, health-conscious, and environmentally friendly: Positive impressions of insect food product consumers. Food Qual. Prefer. 2018, 68, 64-71. [CrossRef]

39. Ruby, M.B.; Heine, S.J. Meat, morals, and masculinity. Appetite 2011, 56, 447-450. [CrossRef] [PubMed]

40. Sadalla, E.; Burroughs, J. Profiles in Eating: Sexy Vegetarians and Other Diet-Based Social Stereotypes. Psychol. Today 1981, $15,51-57$.

41. Jabs, J.; Devine, C.M.; Sobal, J. Model of the Process of Adopting Vegetarian Diets: Health Vegetarians and Ethical Vegetarians. J. Nutr. Educ. 1998, 30, 196-202. [CrossRef]

42. Beardsworth, A.; Keil, T. Health-related beliefs and dietary practices among vegetarians and vegans: A qualitative study. Health Educ. J. 1991, 50, 38-42. [CrossRef]

43. Adams, C.J. The Sexual Politics of Meat: A Feminist-Vegetarian Critical Theory; Bloomsbury revelations edition, reprinted; Bloomsbury Academic an imprint of Bloomsbury Publishing Inc.: New York, NY, USA; London, UK; Oxford, UK; New Delhi, India; Sydney, Australia, 2017; ISBN 9781501312830.

44. Campbell-Arvai, V. Food-related environmental beliefs and behaviours among university undergraduates. Int. J. Sustain. High Educ. 2015, 16, 279-295. [CrossRef]

45. Lea, E.; Worsley, A. Australian consumers' food-related environmental beliefs and behaviours. Appetite 2008, 50, 207-214. [CrossRef]

46. Graham, T.; Abrahamse, W. Communicating the climate impacts of meat consumption: The effect of values and message framing. Glob. Environ. Chang. 2017, 44, 98-108. [CrossRef]

47. Randers, L.; Grønhøj, A.; Thøgersen, J. Coping with multiple identities related to meat consumption. Psychol. Mark. 2021, 38, 159-182. [CrossRef]

48. Gerber, P.J.; Steinfeld, H.; Henderson, B.; Mottet, A.; Opio, C.; Dijkman, J.; Falcucci, A.; Tempio, G. Tackling Climate Change Through Livestock: A Global Assessment of Emissions and Mitigation Opportunities. 2013. Available online: http://www.fao. org/3/i3437e/i3437e.pdf (accessed on 10 November 2021). 
49. Weindl, I.; Popp, A.; Bodirsky, B.L.; Rolinski, S.; Lotze-Campen, H.; Biewald, A.; Humpenöder, F.; Dietrich, J.P.; Stevanović, M. Livestock and human use of land: Productivity trends and dietary choices as drivers of future land and carbon dynamics. Glob. Planet. Chang. 2017, 159, 1-10. [CrossRef]

50. Perignon, M.; Vieux, F.; Soler, L.-G.; Masset, G.; Darmon, N. Improving diet sustainability through evolution of food choices: Review of epidemiological studies on the environmental impact of diets. Nutr. Rev. 2017, 75, 2-17. [CrossRef]

51. van Huis, A. Edible insects contributing to food security? Agric. Food Secur. 2015, 4, 20. [CrossRef]

52. André, Q.; Chandon, P.; Haws, K. Healthy Through Presence or Absence, Nature or Science?: A Framework for Understanding Front-of-Package Food Claims. J. Public Policy Mark. 2019, 38, 172-191. [CrossRef]

53. Rozin, P. The Meaning of Food in Our Lives: A Cross-Cultural Perspective on Eating and Well-Being. J. Nutr. Educ. Behav. 2005, 37, S107-S112. [CrossRef]

54. Wild, F.; Czerny, M.; Janssen, A.M.; Kole, A.; Zunabovic, M.; Domig, K.J. The evolution of a plant-based alternative to meat. From niche markets to widely accepted meat alternatives. Agro Food Ind. Hi-Tech 2014, 25, 45-49.

55. Tu, V.P.; Husson, F.; Sutan, A.; Ha, D.T.; Valentin, D. For me the taste of soy is not a barrier to its consumption. And how about you? Appetite 2012, 58, 914-921. [CrossRef]

56. Bawa, A.S.; Anilakumar, K.R. Genetically modified foods: Safety, risks and public concerns-a review. J. Food Sci. Technol. 2013, 50, 1035-1046. [CrossRef] [PubMed]

57. Southey, F. 'Plant-based', 'Vegan', or Vegetarian'?: Consumers Reveal Attitudes to Diet Descriptions. Available online: https://www.foodnavigator.com/Article/2019/10/25/Plant-based-vegan-or-vegetarian-Consumers-reveal-attitudes-to-dietdescriptions (accessed on 28 October 2021).

58. Peters, J.; Beck, J.; Lande, J.; Pan, Z.; Cardel, M.; Ayoob, K.; Hill, J.O. Using Healthy Defaults in Walt Disney World Restaurants to Improve Nutritional Choices. J. Assoc. Consum. Res. 2016, 1, 92-103. [CrossRef]

59. Lemken, D.; Spiller, A.; Schulze-Ehlers, B. More room for legume-Consumer acceptance of meat substitution with classic, processed and meat-resembling legume products. Appetite 2019, 143, 104412. [CrossRef]

60. Pohjolainen, P.; Vinnari, M.; Jokinen, P. Consumers' perceived barriers to following a plant-based diet. Br. Food J. 2015, 117, 1150-1167. [CrossRef]

61. Elzerman, J.E.; van Boekel, M.A.; Luning, P.A. Exploring meat substitutes: Consumer experiences and contextual factors. Br. Food J. 2013, 115, 700-710. [CrossRef]

62. Collier, E.S.; Oberrauter, L.-M.; Normann, A.; Norman, C.; Svensson, M.; Niimi, J.; Bergman, P. Identifying barriers to decreasing meat consumption and increasing acceptance of meat substitutes among Swedish consumers. Appetite 2021, 167, 105643. [CrossRef]

63. Martin, C.; Lange, C.; Marette, S. Importance of additional information, as a complement to information coming from packaging, to promote meat substitutes: A case study on a sausage based on vegetable proteins. Food Qual. Prefer. 2021, 87, 104058. [CrossRef]

64. Cohen, M. Impossible Foods, Beyond Meat Battle to Achieve Price Parity with Real Meat. Available online: https:/ /www.cnbc com/2021/08/25/impossible-foods-beyond-meat-battle-price-parity-with-real-meat.html (accessed on 28 October 2021).

65. McDonald, S.; Oates, C.J.; Alevizou, P.J. No Through Road: A Critical Examination of Researcher Assumptions and Approaches to Researching Sustainability. In Marketing in and for a Sustainable Society; Malhotra, N.K., Ed.; Emerald Group Publishing Limited: Bingley, UK, 2016; pp. 139-168. ISBN 9781786352811.

66. Graça, J.; Calheiros, M.M.; Oliveira, A. Attached to meat? (Un)Willingness and intentions to adopt a more plant-based diet. Appetite 2015, 95, 113-125. [CrossRef]

67. Pliner, P.; Salvy, S.-J. Food Neophobia in Humans. In The Psychology of Food Choice; CABI: Wallinford, UK, 2006 ; pp. 75-92. ISBN 0851990320.

68. Lea, E.; Worsley, A. Benefits and barriers to the consumption of a vegetarian diet in Australia. Public Health Nutr. 2003, 6, 505-511. [CrossRef] [PubMed]

69. Edwards, J.S.A.; Hartwell, H.L.; Brown, L. Changes in food neophobia and dietary habits of international students. J. Hum. Nutr. Diet. 2010, 23, 301-311. [CrossRef]

70. Hoek, A.C.; Elzerman, J.E.; Hageman, R.; Kok, F.J.; Luning, P.A.; de Graaf, C. Are meat substitutes liked better over time? A repeated in-home use test with meat substitutes or meat in meals. Food Qual. Prefer. 2013, 28, 253-263. [CrossRef]

71. Biermann, G.; Rau, H. The meaning of meat: (Un)sustainable eating practices at home and out of home. Appetite 2020, $153,104730$. [CrossRef] [PubMed]

72. Lea, E.J.; Crawford, D.; Worsley, A. Consumers' readiness to eat a plant-based diet. Eur. J. Clin. Nutr. 2006, 60, 342-351. [CrossRef] [PubMed]

73. Nakagawa, S.; Hart, C. Where's the Beef? How Masculinity Exacerbates Gender Disparities in Health Behaviors. Socius 2019, 5, 237802311983180. [CrossRef]

74. de Backer, C.; Erreygers, S.; de Cort, C.; Vandermoere, F.; Dhoest, A.; Vrinten, J.; van Bauwel, S. Meat and masculinities. Can differences in masculinity predict meat consumption, intentions to reduce meat and attitudes towards vegetarians? Appetite 2020, 147, 104559. [CrossRef]

75. Beekman, V. You are What You Eat: Meat, Novel Protein Foods, and Consumptive Freedom. J. Agric. Environ. Ethics 2000, 12, 185-196. [CrossRef] 
76. Sahakian, M.; Godin, L.; Courtin, I. Promoting 'pro', 'low', and 'no' meat consumption in Switzerland: The role of emotions in practices. Appetite 2020, 150, 104637. [CrossRef]

77. Corrin, T.; Papadopoulos, A. Understanding the attitudes and perceptions of vegetarian and plant-based diets to shape future health promotion programs. Appetite 2017, 109, 40-47. [CrossRef] [PubMed]

78. Circus, V.E.; Robison, R. Exploring perceptions of sustainable proteins and meat attachment. Br. Food J. 2019, 121, 533-545. [CrossRef]

79. McBey, D.; Watts, D.; Johnstone, A.M. Nudging, formulating new products, and the lifecourse: A qualitative assessment of the viability of three methods for reducing Scottish meat consumption for health, ethical, and environmental reasons. Appetite 2019, 142, 104349. [CrossRef]

80. Hwang, J.; You, J.; Moon, J.; Jeong, J. Factors Affecting Consumers' Alternative Meats Buying Intentions: Plant-Based Meat Alternative and Cultured Meat. Sustainability 2020, 12, 5662. [CrossRef]

81. Tso, R.; Forde, C.G. Unintended Consequences: Nutritional Impact and Potential Pitfalls of Switching from Animal- to Plant-Based Foods. Nutrients 2021, 13, 2527. [CrossRef] [PubMed]

82. Leroy, F.; Praet, I. Meat traditions. The co-evolution of humans and meat. Appetite 2015, 90, 200-211. [CrossRef] [PubMed]

83. Bublitz, M.G.; Peracchio, L.A.; Block, L.G. Why did I eat that? Perspectives on food decision making and dietary restraint. J. Consum. Psychol. 2010, 20, 239-258. [CrossRef]

84. Lea, E.; Worsley, A.; Crawford, D. Australian adult consumers' beliefs about plant foods: A qualitative study. Health Educ. Behav. 2005, 32, 795-808. [CrossRef]

85. Michel, F.; Hartmann, C.; Siegrist, M. Consumers' associations, perceptions and acceptance of meat and plant-based meat alternatives. Food Qual. Prefer. 2021, 87, 104063. [CrossRef]

86. Köpetz, C.E.; Kruglanski, A.W.; Arens, Z.G.; Etkin, J.; Johnson, H.M. The Dynamics of Consumer Behavior: A Goal Systemic Perspective. J. Consum. Psychol. 2012, 22, 208-223. [CrossRef]

87. Belei, N.; Geyskens, K.; Goukens, C.; Ramanathan, S.; Lemmink, J. The Best of Both Worlds? Effects of Attribute-Induced Goal Conflict on Consumption of Healthful Indulgences. J. Mark. Res. 2012, 49, 900-909. [CrossRef]

88. Fishbach, A.; Dhar, R. Goals as Excuses or Guides: The Liberating Effect of Perceived Goal Progress on Choice. J. Consum. Res. 2005, 32, 370-377. [CrossRef]

89. Vermeir, I.; Weijters, B.; de Houwer, J.; Geuens, M.; Slabbinck, H.; Spruyt, A.; van Kerckhove, A.; van Lippevelde, W.; de Steur, H.; Verbeke, W. Environmentally Sustainable Food Consumption: A Review and Research Agenda from a Goal-Directed Perspective. Front. Psychol. 2020, 11, 1603. [CrossRef]

90. Melendrez-Ruiz, J.; Chambaron, S.; Buatois, Q.; Monnery-Patris, S.; Arvisenet, G. A central place for meat, but what about pulses? Studying French consumers' representations of main dish structure, using an indirect approach. Food Res. Int. 2019, 123, 790-800. [CrossRef]

91. CNN. Life But Better-Food: The World's 50 Best Foods. Available online: https://edition.cnn.com/travel/article/world-bestfood-dishes/index.html (accessed on 29 October 2021).

92. The Guardian. What's Your Favorite Food? Available online: https://www.theguardian.com/lifeandstyle/wordofmouth/2011 /jun/16/whats-your-favourite-food (accessed on 29 October 2021).

93. Kubberød, E.; Ueland, Ø.; Tronstad, A.; Risvik, E. Attitudes towards meat and meat-eating among adolescents in Norway: A qualitative study. Appetite 2002, 38, 53-62. [CrossRef]

94. Raghunathan, R.; Naylor, R.W.; Hoyer, W.D. The Unhealthy = Tasty Intuition and Its Effects on Taste Inferences, Enjoyment, and Choice of Food Products. J. Mark. 2006, 70, 170-184. [CrossRef]

95. Wertenbroch, K. Consumption Self-Control by Rationing Purchase Quantities of Virtue and Vice. Mark. Sci. 1998, 17, 317-337. [CrossRef]

96. van Doorn, J.; Verhoef, P.C. Willingness to pay for organic products: Differences between virtue and vice foods. Int. J. Res. Mark. 2011, 28, 167-180. [CrossRef]

97. Milkman, K.L.; Rogers, T.; Bazerman, M.H. I'll have the ice cream soon and the vegetables later: A study of online grocery purchases and order lead time. Mark. Lett. 2010, 21, 17-35. [CrossRef]

98. Okada, E.M. Justification Effects on Consumer Choice of Hedonic and Utilitarian Goods. J. Mark. Res. 2005, 42, 43-53. [CrossRef]

99. Baumeister, R.F.; Vohs, K.D. Strength Model of Self-Regulation as Limited Resource. Adv. Exp. Soc. Psychol. 2016, 54, 67-127. [CrossRef]

100. Lin, H.; Saunders, B.; Friese, M.; Evans, N.J.; Inzlicht, M. Strong Effort Manipulations Reduce Response Caution: A Preregistered Reinvention of the Ego-Depletion Paradigm. Psychol. Sci. 2020, 31, 531-547. [CrossRef]

101. Baumeister, R.F. Yielding to Temptation: Self-Control Failure, Impulsive Purchasing, and Consumer Behavior. J. Consum. Res. 2002, 28, 670-676. [CrossRef]

102. Dhar, R.; Simonson, I. Making Complementary Choices in Consumption Episodes: Highlighting Versus Balancing. J. Mark. Res. 1999, 36, 29-44. [CrossRef]

103. Chang, C.-T.; Chu, X.-Y. The give and take of cause-related marketing: Purchasing cause-related products licenses consumer indulgence. J. Acad. Mark. Sci. 2020, 48, 203-221. [CrossRef]

104. Chernev, A.; Böckenholt, U.; Goodman, J. Choice overload: A conceptual review and meta-analysis. J. Consum. Psychol. 2015, 25, 333-358. [CrossRef] 
105. Gailliot, M.T.; Baumeister, R.F.; DeWall, C.N.; Maner, J.K.; Plant, E.A.; Tice, D.M.; Brewer, L.E.; Schmeichel, B.J. Self-control relies on glucose as a limited energy source: Willpower is more than a metaphor. J. Personal. Soc. Psychol. 2007, 92, 325-336. [CrossRef] [PubMed]

106. Danziger, S.; Levav, J.; Avnaim-Pesso, L. Extraneous factors in judicial decisions. Proc. Natl. Acad. Sci. USA 2011, 108, 6889-6892. [CrossRef]

107. Hunt, J.R. Moving toward a plant-based diet: Are iron and zinc at risk? Nutr. Rev. 2002, 60, 127-134. [CrossRef]

108. NHS. The Vegan Diet: Eat Well. Available online: https://www.nhs.uk/live-well/eat-well/the-vegan-diet/ (accessed on 28 October 2021).

109. American Dietetic Association; Dietitians of Canada. Position of the American Dietetic Association and Dietitians of Canada: Vegetarian diets. J. Am. Diet. Assoc. 2003, 103, 748-765. [CrossRef] [PubMed]

110. Estell, M.; Hughes, J.; Grafenauer, S. Plant Protein and Plant-Based Meat Alternatives: Consumer and Nutrition Professional Attitudes and Perceptions. Sustainability 2021, 13, 1478. [CrossRef]

111. Bohrer, B.M. An investigation of the formulation and nutritional composition of modern meat analogue products. Food Sci. Hum. Wellness 2019, 8, 320-329. [CrossRef]

112. International Food Information Council. Understanding Our Food Communication Tool Kit: Leader Guide; International Food Information Council: Washington, DC, USA, 2015. Available online: https://foodinsight.org/wp-content/uploads/2014/07/ IFIC_Leader_Guide_high_res.pdf (accessed on 10 November 2021).

113. de Vlieger, N.M.; Collins, C.; Bucher, T. What is a nutritious snack? Level of processing and macronutrient content influences young adults' perceptions. Appetite 2017, 114, 55-63. [CrossRef] [PubMed]

114. Bucher, T.; Müller, B.; Siegrist, M. What is healthy food? Objective nutrient profile scores and subjective lay evaluations in comparison. Appetite 2015, 95, 408-414. [CrossRef]

115. Rozin, P.; Spranca, M.; Krieger, Z.; Neuhaus, R.; Surillo, D.; Swerdlin, A.; Wood, K. Preference for natural: Instrumental and ideational/moral motivations, and the contrast between foods and medicines. Appetite 2004, 43, 147-154. [CrossRef]

116. Varela, P.; Arvisenet, G.; Gonera, A.; Myhrer, K.S.; Fifi, V.; Valentin, D. Meat replacer? No thanks! The clash between naturalness and processing: An explorative study of the perception of plant-based foods. Appetite 2021, 105793. [CrossRef]

117. Prada, M.; Garrido, M.V.; Rodrigues, D. Lost in processing? Perceived healthfulness, taste and caloric content of whole and processed organic food. Appetite 2017, 114, 175-186. [CrossRef]

118. Rozin, P.; Fischler, C.; Shields-Argelès, C. European and American perspectives on the meaning of natural. Appetite 2012, 59, 448-455. [CrossRef]

119. Tuorila, H.; Meiselman, H.L.; Bell, R.; Cardello, A.V.; Johnson, W. Role of sensory and cognitive information in the enhancement of certainty and liking for novel and familiar foods. Appetite 1994, 23, 231-246. [CrossRef] [PubMed]

120. Mookerjee, S.; Cornil, Y.; Hoegg, J. From Waste to Taste: How “Ugly” Labels Can Increase Purchase of Unattractive Produce. J. Mark. 2021, 85, 62-77. [CrossRef]

121. Alevizou, P.; Oates, C.; McDonald, S. The Well(s) of Knowledge: The Decoding of Sustainability Claims in the UK and in Greece. Sustainability 2015, 7, 8729-8747. [CrossRef]

122. Szejda, K.; Bryant, C.J.; Urbanovich, T. US and UK Consumer Adoption of Cultivated Meat: A Segmentation Study. Foods 2021, 10, 1050. [CrossRef] [PubMed]

123. Bryant, C.; Barnett, J. Consumer Acceptance of Cultured Meat: An Updated Review (2018-2020). Appl. Sci. 2020, 10, 5201. [CrossRef]

124. Wilks, M.; Phillips, C.J.C.; Fielding, K.; Hornsey, M.J. Testing potential psychological predictors of attitudes towards cultured meat. Appetite 2019, 136, 137-145. [CrossRef]

125. Cialdini, R.B.; Kallgren, C.A.; Reno, R.R. A Focus Theory of Normative Conduct: A Theoretical Refinement and Reevaluation of the Role of Norms in Human Behavior. Adv. Exp. Soc. Psychol. 1991, 24, 201-234. [CrossRef]

126. Sparkman, G.; Walton, G.M. Dynamic Norms Promote Sustainable Behavior, even if It Is Counternormative. Psychol. Sci. 2017, 28, 1663-1674. [CrossRef]

127. Hui, S.K.; Bradlow, E.T.; Fader, P.S. Testing Behavioral Hypotheses Using an Integrated Model of Grocery Store Shopping Path and Purchase Behavior. J. Consum. Res. 2009, 36, 478-493. [CrossRef]

128. Mishra, A.; Mishra, H. The Influence of Price Discount versus Bonus Pack on the Preference for Virtue and Vice Foods. J. Mark. Res. 2011, 48, 196-206. [CrossRef]

129. Scarpi, D.; Pizzi, G.; Pichierri, M. Eating with Your Eyes: How Packaging Visual Cues Affect Content Estimation and Self-control in Virtue and Vice Food. J. Int. Food Agribus. Mark. 2019, 31, 107-127. [CrossRef]

130. Hofmann, W.; Gschwendner, T.; Friese, M.; Wiers, R.W.; Schmitt, M. Working memory capacity and self-regulatory behavior: Toward an individual differences perspective on behavior determination by automatic versus controlled processes. J. Personal. Soc. Psychol. 2008, 95, 962-977. [CrossRef] [PubMed]

131. Baumeister, R.F.; Heatherton, T.F. Self-Regulation Failure: An Overview. Psychol. Inq. 1996, 7, 1-15. [CrossRef]

132. Kivetz, R.; Zheng, Y. The effects of promotions on hedonic versus utilitarian purchases. J. Consum. Psychol. 2017, 27, 59-68. [CrossRef]

133. Chernev, A.; Gal, D. Categorization Effects in Value Judgments: Averaging Bias in Evaluating Combinations of Vices and Virtues. J. Mark. Res. 2010, 47, 738-747. [CrossRef] 
134. Ein-Gar, D.; Goldenberg, J.; Sagiv, L. The role of consumer self-control in the consumption of virtue products. Int. J. Res. Mark. 2012, 29, 123-133. [CrossRef]

135. Böhm, G.; Pfister, H.-R. Instrumental or emotional evaluations: What determines preferences? Acta Psychol. 1996, 93, 135-148. [CrossRef]

136. Jahn, S.; Tsalis, G.; Lähteenmäki, L. How attitude towards food fortification can lead to purchase intention. Appetite 2019, 133, 370-377. [CrossRef]

137. Bruins, M.J.; Létinois, U. Adequate Vitamin D Intake Cannot Be Achieved within Carbon Emission Limits Unless Food Is Fortified: A Simulation Study. Nutrients 2021, 13, 592. [CrossRef] [PubMed]

138. Weinrich, R.; Elshiewy, O. Preference and willingness to pay for meat substitutes based on micro-algae. Appetite 2019, 142, 104353 [CrossRef] [PubMed]

139. Lazzarini, G.A.; Zimmermann, J.; Visschers, V.H.M.; Siegrist, M. Does environmental friendliness equal healthiness? Swiss consumers' perception of protein products. Appetite 2016, 105, 663-673. [CrossRef] [PubMed]

140. Read, D.; van Leeuwen, B. Predicting Hunger: The Effects of Appetite and Delay on Choice. Organ. Behav. Hum. Decis. Process. 1998, 76, 189-205. [CrossRef] [PubMed]

141. Stroebe, W.; Mensink, W.; Aarts, H.; Schut, H.; Kruglanski, A.W. Why dieters fail: Testing the goal conflict model of eating. J. Exp. Soc. Psychol. 2008, 44, 26-36. [CrossRef]

142. Connors, M.; Bisogni, C.A.; Sobal, J.; Devine, C.M. Managing values in personal food systems. Appetite 2001, 36, 189-200. [CrossRef]

143. Furchheim, P.; Martin, C.; Morhart, F. Being green in a materialistic world: Consequences for subjective well-being. Psychol. Mark. 2020, 37, 114-130. [CrossRef]

144. Minton, E.A.; Cornwell, T.B. The Cause Cue Effect: Cause-Related Marketing and Consumer Health Perceptions. J. Consum. Aff. 2016, 50, 372-402. [CrossRef]

145. Chernev, A.; Blair, S. Doing Well by Doing Good: The Benevolent Halo of Corporate Social Responsibility. J. Consum. Res. 2015, 41, 1412-1425. [CrossRef] 